\title{
Avoiding The Imposition Of Penalties And Sanctions Under Circular 230 On Tax Practitioners
}

John R. Leavins, University of St. Thomas, USA

\begin{abstract}
The Treasury Department and the IRS have established certain standards for those who are tax practitioners. Certified Public Accountants and other tax practitioners face potential penalties if they violate those standards. "Treasury Department Circular No. 230" contains the rules that guide practitioners. It also specifies a number of tax preparer penalties and sanctions that can be imposed on those who "practice before the IRS." Sanctions can include censure, suspension, disbarment, and the assessment of monetary penalties. The imposition of these sanctions can have a significant negative impact on a CPA's practice. The CPA firm's reputation and its ability to generate income can be adversely affected. The purpose of this article is to summarize the penalties and sanctions contained in Treasury Circular 230. The article also recommends courses of action that tax practitioners should take in order to minimize their exposure to those sanctions.
\end{abstract}

Keywords: Tax Preparer Penalties, Tax Preparer Sanctions, IRS Circular 230

\section{INTRODUCTION}

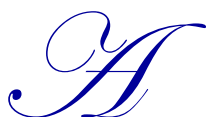

significant amount of work performed by CPA firms involves tax preparation and giving tax advice to clients. The Secretary of the Treasury is given the authority to develop rules and regulations governing tax preparers and those who represent taxpayers before the IRS. These regulations are published in a pamphlet referred to as "Treasury Department Circular No. 230." The Internal Revenue Service Office of Professional Responsibility (OPR) enforces standards of conduct for tax professionals that are covered by Circular 230.

It carries out disciplinary procedures against those who violate the rules of Circular 230 and it is also responsible for determining who is eligible to practice before the IRS. The purpose of this article is to explore the penalties and other sanctions applicable to certified public accountants (CPAs) under Circular 230. It also suggests ways for CPAs to avoid these penalties and sanctions.

\section{THE CONCEPT OF "PRACTICE BEFORE THE IRS"}

Treasury Circular 230 is applicable to those who "practice before the IRS." Understanding this concept is very important for tax practitioners and encompasses much more than just preparing and filing tax returns. The concept includes representing taxpayers at meetings, hearing and conferences. It also includes written correspondence regarding tax matters between the practitioner and the client and written correspondence between the practitioner and the IRS.

This means that even if one is not a tax-return preparer, one may be a practitioner. It is also important to note that even if a practitioner has had no contact with the IRS, he or she may be disciplined by OPR for inappropriately rendering written advice to a taxpayer. Thus, practitioners must be especially careful when any form of written communication is made with taxpayers or the IRS because Circular 230 would apply and possibly subject the practitioner to any applicable penalties and sanctions. 


\section{SANCTIONS UNDER CIRCULAR 230}

When a tax practitioner violates the rules and regulations published in Circular 230, the IRS is authorized to impose four different types of sanctions. These are censure, suspension, disbarment, and the assessment of monetary penalties. Censure is an official public reprimand of the practitioner and is generally carried out by a resolution condemning a person for misconduct. Censure is usually accomplished by a notice published in the Federal Register. The Federal Register is the daily legal newspaper of the Federal government and is published every business day by the National Archives and Records Administration.

Censure does not prohibit the practitioner from practicing before the IRS and is usually imposed for a limited time period. The OPR may also impose additional conditions on the practitioner in conjunction with censure. The severity of those conditions depends on the seriousness of the practitioner's violations. Of the three non-monetary sanctions that may be imposed, the least punitive is censure. However, censure sends a strong message to the practitioner and his or her colleagues concerning the practitioner's fitness.

The second type of sanction that might be imposed on a practitioner is suspension. Suspension prohibits a CPA from practicing before the IRS and it may be imposed for a specified period of time or for a period of indefinite duration. An individual that is suspended is prohibited from representing taxpayers before the Internal Revenue Service during the term of the suspension.

The third type of sanction is disbarment. Disbarment is the most severe sanction that can be administered under Circular 230. If a CPA is disbarred, he or she may not practice in any manner before the IRS. The regulations do not provide any standards for determining when it is appropriate to order disbarment as opposed to suspension.

Disbarment is similar to suspension in that it makes the practitioner ineligible to practice before the Internal Revenue Service. Unlike suspension, however, disbarment may or may not be temporary. In many cases, a disbarred practitioner may reapply for the privilege of representing taxpayers before the Internal Revenue Service after a specified period during which he or she may not practice. In the case of suspension or disbarment, Circular 230 specifically states that the following may not be performed during suspension or disbarment:

1. Prepare or file tax returns or correspond with the IRS;

2. Render written tax advice;

3. Represent a taxpayer at any form of meeting or hearing;

4. Receive a client's refund check or sign a tax return on behalf of a client;

5. File a power of attorney with the IRS, and

6. Represent to others that he or she is eligible to practice before the IRS.

The fourth type of sanction that may be imposed on a practitioner is the assessment of a monetary penalty. A monetary penalty may be imposed in addition to, or in place of, suspension, disbarment, or censure. There is no set or standard penalty amount and the specific amount of any monetary penalty imposed is left to the discretion of the OPR. However, the law does provide a limitation on the dollar amount of the monetary penalty that may be imposed. The maximum amount that can be imposed is limited to the amount of gross income that is derived from the conduct giving rise to the penalty.

Furthermore, when an individual violates the provisions of Circular 230, the OPR may also levy a monetary penalty against that person's firm or employer if it is determined that the firm or employer knew of the prohibited conduct. CPA firms need to provide careful oversight of its employees since the actions of a CPA who is employed by a CPA firm can cause the firm to suffer a penalty.

The four types of sanctions mentioned above will generally only be imposed if the conduct is willful or intentional. However, willfulness is not required when the violation involves several types of conduct. These are (1) taking a frivolous position on a tax return matter; (2) failing to advise a client of likely penalties related to a position taken on a tax return; or (3) rendering inappropriate written tax advice to a taxpayer. With respect to these three 
categories of conduct, the OPR does not have to show that the practitioner acted willfully, but only that the activity took place.

\section{THE PROCESS OF IMPOSING SANCTIONS}

When a sanction is imposed, it generally begins with a complaint served on the practitioner. The complaint must specify the sanction being sought and the practitioner must file a written answer. The next step in the process is a hearing conducted by an Administrative Law Judge (ALJ). Each side presents evidence and the ALJ issues a decision regarding the imposition of the sanction. Either party may appeal the ALJ's decision to the IRS Office of Chief Counsel. If the imposition of the sanction is appealed, the Office of Chief Counsel may uphold the sanction, overturn it, or modify it. Modification could actually include increasing the severity of the sanction. Either party may further appeal the decision of the Office of Chief Counsel to the U.S. District Court. At this point, the decision will only be overturned if the federal judge determines that the decision was arbitrary, capricious, an abuse of discretion or "unsupported by substantial evidence."

In special cases, a practitioner may be suspended from practicing before the IRS solely as a result of a conference with the OPR. In these cases, no hearing is required. These circumstances include situations when a practitioner has (1) had his or her professional license suspended or revoked; (2) been convicted of any tax crime, or been convicted of a felony that renders the practitioner unfit to practice before the IRS; (3) been sanctioned by a court for actions related to the determination of a taxpayer's tax liability; or (4) been sanctioned for actions related to the practitioner's own tax liability.

\section{INCOMPETENCE AND DISREPUTABLE CONDUCT}

Sanctions may be imposed on tax practitioners if they demonstrate incompetence or engage in disreputable conduct. Circular 230 does not define the terms "incompetence" and does not distinguish between the concepts of "incompetence" and "disreputable conduct." Instead, it provides a list of specific instances that fall under those general concepts. The list of incompetent or disreputable activities contained in Circular 230 includes:

1. Conviction of any criminal offense under federal tax law;

2. Conviction of any criminal offense involving breach of trust or dishonesty;

3. Conviction of a felony that renders the practitioner unfit to practice before the IRS;

4. Giving false or misleading information to federal tax authorities;

5. Indicating that special treatment can be obtained from the IRS;

6. Willfully failing to file a federal return or pay federal taxes;

7. Willfully assisting, counseling, or encouraging the violation of federal tax law;

8. Mishandling funds received from a client for the payment of taxes;

9. False accusations, threats, duress, coercion, or bribery of an IRS employee;

10. Disbarment or suspension from practice;

11. Knowingly assisting another who is suspended or disbarred from practice;

12. Using abusive, malicious, or libelous language in a matter before the IRS;

13. Inappropriate actions regarding the issuance of opinions;

14. Willfully failing to sign a tax return prepared by the tax preparer; and

15. The inappropriate and willful disclosure or use of tax information.

\section{THE CONCEPT OF GROSS INCOMPETENCE}

The term gross incompetence" focuses on the practitioner's lack of attention to client matters. Such conduct would include actions that reflect gross indifference to laws and regulations or a consistent failure to perform obligations in client related matters. Also, the failure to adequately prepare for an activity involving a tax-related matter can be considered gross incompetence.

Incompetence may also arise from adopting or aiding taxpayers with so-called "tax protester" positions. These are positions taken by taxpayers that are based on unsupported interpretations of the law. An example of this 
is the tax protester position that compensation for personal services is not income because a person is exchanging labor for money. Another tax protester position is that the federal income tax is illegal because the Sixteenth Amendment to the United States Constitution was never ratified. Other examples include the argument that only foreign-source income is taxable or that the term "income" as used in the Code is unconstitutionally vague. These and numerous other tax protester positions have been clearly addressed by the courts and have been determined to be invalid.

\section{SUSPENSION OR DISBARMENT FOR FAILURE TO FILE}

Suspension or disbarment can result from a practitioner's failure to file or pay his or her own personal tax obligations. Precedent seems to indicate that a practitioner's failure to file or pay tax obligations for five consecutive years will often result in disbarment. In almost every reported case resulting in disbarment, the practitioner either failed to file or failed to pay his or her tax obligations in a timely manner for five or more years.

In some cases, lack of filing tax returns or nonpayment of taxes can result in the OPR invoking suspension instead of disbarment. This is often the case when the practitioner has not filed or paid tax obligations but the time period is less than the five years mentioned above. Suspension may also be imposed for filing returns late or for paying taxes late. Some practitioners have attempted to use excuses involving medical or marital problems as reasonable cause for failure to file. These excuses are typically ineffective as a defense for failure to file, particularly if the accused practitioner has continued to prepare and file returns for clients during the relevant period. It is also difficult for a practitioner to use the argument of lack of knowledge about filing requirements since practitioners are obviously quite knowledgeable about these matters.

\section{SANCTIONS IMPOSED FOR CONTEMPTUOUS CONDUCT}

Practitioners use a variety of approaches in dealing with the IRS. Some prefer to maintain a cordial, polite relationship and some are more adversarial in nature. Although practitioners are expected to zealously represent their clients, sometimes the line between zealousness and abusive behavior is crossed. The IRS prohibits "contemptuous" conduct by a tax practitioner. Circular 230 gives several examples of contemptuous behavior. These include the use of abusive language, making false accusations, or circulating malicious or libelous matter. Practitioners should be careful in their choice of words in dealing with IRS employees because the use of threats, false accusations, or coercion can lead to sanctions.

\section{ISSUES REGARDING FEE STRUCTURES}

There are certain rules regarding fees charged by tax practitioners. First, a practitioner is prohibited from charging a fee that is exorbitant when representing a client in a matter before the IRS. This rule includes issues involving tax planning and advice, preparing or filing returns, and all other matters connected with representing a client before the Internal Revenue Service.

There are also limitations on a practitioner that charges contingent fees. A contingent fee includes a fee that is based on a percentage of the refund reported on a return or that is based on a percentage of the taxes saved. A contingent fee also includes a fee that is based on whether or not a position taken on a tax return avoids challenge by the Internal Revenue Service. A practitioner may not charge a contingent fee for preparing an original tax return or for any advice rendered in connection with a position taken on an original tax return.

However, once a client tax return has been filed, a contingent fee may be charged for services rendered in connection with an IRS examination of the return. In addition, a practitioner may charge a contingent fee for services rendered in connection with any judicial proceeding arising under the Internal Revenue Code.

\section{KNOWLEDGE OF CLIENT ERRORS OR OMISSIONS}

Tax practitioners often face situations where information provided by a client is inaccurate. A practitioner has certain obligations if he or she knows that the information supplied by the client is inaccurate. Circular No. 230 
states that a practitioner who knows that the client has provided false or inaccurate information has a positive duty to make certain disclosures to the client. Those disclosures require the practitioner to do the following:

- $\quad$ Advise the client that he or she has failed to comply with U.S. tax laws, and

- $\quad$ Advise the client of the consequences of the failure to comply with the appropriate law or regulation.

A question often arises regarding whether or not a practitioner is required to withdraw from providing services to a client if the client refuses to amend a previously filed inaccurate return or otherwise failed to comply with certain tax laws. A CPA in this situation is not required to withdraw from providing services to the client. However, if a taxpayer refuses to correct a prior incorrect return, the tax preparer might seriously consider the wisdom of continuing a relationship with that client.

\section{ISSUES REGARDING CLIENT RECORDS}

It is not uncommon for a client to provide a practitioner with various records to substantiate his or her income, expenditures, deductions, etc. Treasury Circular 230 addresses the issue of the responsibility of a tax practitioner to return taxpayer records. Although a tax practitioner may retain copies of the records returned to a client, the practitioner must promptly return any and all requested records to the client. In the context of requiring the CPA to return client records, the term "records" includes all of materials provided to the practitioner in connection with the engagement.

Often, a practitioner's refusal to return a client's results from a dispute over fees payable for the practitioner's work. The existence of such a dispute generally does not relieve the practitioner of his or her responsibility to return client records as defined above. However, the term "records of the client" does not include documents prepared by the practitioner. Hence, a practitioner does not have to provide the client with practitionerprepared documents until the client meets his or her contractual obligations regarding compensation for the practitioner's services.

\section{UNREASONABLE TAX POSITIONS}

Due to the complexity and ambiguity of much of the tax code and regulations, practitioners often have to make difficult decisions regarding the taxability of certain types of income and the deductibility of particular items. A tax practitioner must have a reasonable basis when a position is taken on a tax return. If a practitioner takes a tax return position that the practitioner knows is unreasonable, the tax practitioner can be subject to a penalties. A position is treated as unreasonable unless:

1. There was substantial authority for the position taken, or

2. The position is adequately disclosed and is deemed reasonable.

The penalty is the greater of $\$ 1,000$ or 50 percent of the income derived by the practitioner from the return. If the unreasonable position resulted in an underpayment of taxes by a taxpayer and is deemed to be willful and reckless, the penalty increases to the greater of $\$ 5,000$ or 50 percent of the income derived from the preparation of the return. The penalty may decrease if the practitioner shows there was reasonable cause for the understatement and the practitioner acted in good faith.

\section{CONCLUSION}

All firms whose employees practice before the IRS should require that the firm's practitioners be familiar with Circular 230. Once an allegation is made, the firm or employer should conduct its own investigation, isolate the circumstances that allowed the alleged infraction to occur, and take appropriate remedial action to prevent a recurrence.

A disciplinary hearing under Circular 230 should be taken very seriously. The CPA should consider legal counsel since the hearing is governed by specific rules of evidence. Practitioners who do not have professional 
liability insurance should carefully consider the benefits of such a policy in light of potential Circular 230 violations or other potential legal matters. The professional liability insurance carrier will often cover the cost of legal representation should the CPA need it.

Tax practitioners should be conscious of the fact that a Circular 230 violation can have a significant negative impact a CPA's reputation and ability to practice. Being proactive and responding in a responsible way to allegations of Circular 230 infractions is a practitioner's best defense against the imposition of sanctions.

\section{AUTHOR INFORMATION}

John R. Leavins, PhD, CPA, CIA is Chair and Professor of Accounting at the University of St. Thomas in Houston, Texas. His specialties are Accounting Information Systems, Taxation and Auditing.

\section{REFERENCES}

1. $\quad$ Circular 230, Title 31 U.S.C. \$330, 31 C.F.R. Subtitle A, Part 10.

2. "Ethical Considerations for CPA's," Surgent McCoy Self-Study, LLC, 2012

3. Goller, Michael G., "Practitioners Take Note: Now is a Good Time for a Circular 230 Refresher," Journal of Tax Practice and Procedure, June-July, 2012.

4. Placid, Raymond L. and H Wayne Cecil, "Tax Preparer Penalties: Who is a Preparer?" The Tax Advisor, August 2009.

5. Rood, Deborah, "Tax Return Preparation Penalties: Really?” On Balance, January-February 2013.

6. Skarlatos, Bryan, "Civil Penalties for Tax Return Preparers," Journal of Tax Practice and Procedure, August-September 2013.

7. "The Reach of Circular 230," The Journal of Accountancy, February 2012. 